\title{
Article
}

\section{Time Points for Gonadotropin-Releasing Hormone Stimulation Test Results in Korean Children}

\author{
Rihwa Choi ${ }^{1,2} \mathbb{D}$, Aerin Kwon ${ }^{2}$, Youngju Oh ${ }^{2} \mathbb{D}$, Sang Gon Lee ${ }^{2, * \mathbb{D}}$ and Eun Hee Lee ${ }^{3, *}$ \\ 1 Department of Laboratory Medicine and Genetics, Samsung Medical Center, Sungkyunkwan University \\ School of Medicine, Seoul 06351, Korea; rihwa.choi@gclabs.co.kr \\ 2 Department of Laboratory Medicine, Green Cross Laboratories, Yongin, Gyeonggi 16924, Korea; \\ aerinkwon@gclabs.co.kr (A.K.); yjoh@gclabs.co.kr (Y.O.) \\ 3 Green Cross Laboratories, Yongin, Gyeonggi 16924, Korea \\ * Correspondence: sglee@gclabs.co.kr (S.G.L.); ehlee@gclabs.co.kr (E.H.L.); Tel.: +82-32-260-9209 (S.G.L.); \\ +82-1566-0131 (E.H.L.)
}

check for updates

Citation: Choi, R.; Kwon, A.; Oh, Y.; Lee, S.G.; Lee, E.H. Time Points for Gonadotropin-Releasing Hormone Stimulation Test Results in Korean Children. J. Clin. Med. 2021, 10, 252. https://doi.org/10.3390/jcm10020252

Received: 30 October 2020 Accepted: 7 January 2021 Published: 12 January 2021

Publisher's Note: MDPI stays neutral with regard to jurisdictional clai$\mathrm{ms}$ in published maps and institutional affiliations.

Copyright: () 2021 by the authors. Licensee MDPI, Basel, Switzerland. This article is an open access article distributed under the terms and conditions of the Creative Commons Attribution (CC BY) license (https:// creativecommons.org/licenses/by/ $4.0 /)$.

\begin{abstract}
The gold standard for the laboratory diagnosis of central precocious puberty is based on the measurement of luteinizing hormone $(\mathrm{LH})$ after gonadotropin-releasing hormone $(\mathrm{GnRH})$ stimulation. We sought to investigate the laboratory data for $\mathrm{GnRH}$ stimulation testing using samples collected from Korean children at different time points. Sampling times were at the basal time point (0) and 15, 30, 45, 60, 90, and 120 min after GnRH stimulation. Pubertal response was defined as occurring when the peak $\mathrm{LH}$ concentration was $5 \mathrm{IU} / \mathrm{L}$ or more and rose to at least 2 times the basal LH concentration after GnRH stimulation. During the study period, 19,990 test results from 1958 Korean children (1841 females aged 1.3-8.9 years and 117 males aged 7.3-9.9 years) were obtained. Among the 1958 children, 1232 (62.9\%) showed pubertal responses. The receiver operating characteristic curve that demonstrated the greatest area under the curve (AUC) among all examined time points was 45 min after GnRH stimulation in males (AUC 0.982, 95\% CI 0.938-0.998) and 60 min in females (AUC $0.975,95 \%$ CI 0.967-0.981). The combination of $45 \mathrm{~min}$ and $60 \mathrm{~min}$ showed the greatest AUC (0.996, 95\% confidence interval 0.991-0.998), with a sensitivity level of $99.1 \%$ and a specificity of $100 \%$ for all children. The results of this study provide a possibility for a reduction in sampling time points ( $45 \mathrm{~min}$ and $60 \mathrm{~min}$ ) to identify the presence of a pubertal response after $\mathrm{GnRH}$ stimulation in Korean children.
\end{abstract}

Keywords: precocious puberty; GnRH stimulation; luteinizing hormone; Korea; children

\section{Introduction}

Gonadotropin-releasing hormone $(\mathrm{GnRH})$ stimulation tests are used to identify central precocious puberty in children [1]. Puberty results when the pulsatile secretion of GnRH is initiated and the hypothalamic-pituitary-gonadal axis is activated [2]. Thus, the most common cause of progressive precocious puberty (either central (CPP) or gonadotropindependent precocious puberty) is the early activation of pulsatile GnRH secretion, which may result from the presence of hypothalamic tumors or lesions [1,2]. In most cases, however, the cause remains unexplained [1,2]. Clinical findings related to CPP are very similar to those for physiological pubertal development, other than chronological age-younger than the normal age range of onset of puberty is (i.e., before eight years in girls and nine years in boys) [1,3]. It is important to distinguish between CPP and common variants of precocious puberty, such as premature thelarche (defined by the isolated development of breast tissue, without any other pubertal findings, which usually regresses over several months) or premature adrenarche (characterized by pubic or axillary hair growth secondary to mildly increased concentrations of adrenal-derived androgens without accompanying breast or testicular enlargement) [1-3]. However, early breast or testicular development is not always a manifestation of CPP, and clinical and laboratory 
investigations can help to resolve the diagnosis [1]. In South Korea, parents and their children visit pediatric clinics and undergo evaluation for $\mathrm{CPP}$ because of concerns including early menarche in girls and short adult stature due to early epiphyseal fusion and adverse psychosocial outcomes in both sexes [4,5].

Although baseline random luteinizing hormone (LH), GnRH-stimulated folliclestimulating hormone (FSH), the LH to FSH ratio, levels of testosterone, estradiol, and other hormones, and hormonal binding protein profile analysis can be used in the evaluation of precocious puberty, the gold-standard for biochemical diagnosis involves the assessment of LH after stimulation with exogenous LH-releasing hormone (LHRH), GnRH, or GnRH agonists [2,6]. Although different stimulation test protocols have been described, and it has been reported that LH levels vary according to the assay used, the most commonly used stimulated peak LH concentration cut-off value is $5 \mathrm{IU} / \mathrm{L}[1,2]$. This test requires blood sampling to be performed at one or more time points for gonadotrophin measurement at a time point ranging from 15 to $180 \mathrm{~min}$ after intravenous or subcutaneous GnRH administration [1,3,7].

In South Korea, GnRH stimulation test results are required to diagnose and treat CPP with therapeutics in accordance with a national notification (notification number 2017180) released by the Ministry of Health and Welfare of Korea regarding the use of GnRH agonists for treatment of CPP [8]. Multiple time-point blood sampling is comparatively expensive, time consuming, and uncomfortable for patients, and there have been many attempts to simplify this test, e.g., by determining the LH concentration in only a single blood sample obtained at a selected time point $[7,9]$. However, there are no guidelines available regarding the best time point for measurement [3,6,8-10]. The Korean Society of Pediatric Endocrinology's Clinical Guidelines for precocious puberty recommend the consecutive measurement of LH at intervals of 15-30 min from basal conditions to 90 to $120 \mathrm{~min}$ after the application of a standard dose of LHRH $(100 \mu \mathrm{g})$ via injection for GnRH stimulation [8]. The guidelines do not specify exact time points for LH measurement after GnRH stimulation but, rather, allow clinicians to select time points.

Furthermore, limited studies are available regarding the best time point for blood sampling after GnRH stimulation in Korean children [7,11-14]. Previous studies reported differences in hormone concentration ranges of LH and FSH in different ethnic populations using different analytical platforms $[15,16]$. Previous studies conducted to evaluate the best time point for blood sampling after GnRH agonist application in populations other than Korean used different doses of GnRH agonist, limited numbers of male subjects, different LH cut-off values, and different analytical platforms to diagnose CPP [6,17-19].

Previous studies regarding the prevalence of a pubertal response in Korean children who have undergone a GnRH stimulation test and/or time points for blood sampling after GnRH stimulation in Korea included female subjects only or used results from methods other than the electrochemiluminescence immunoassay (ECLIA) [7,11-14]. Due to the pulsatile nature of $\mathrm{GnRH}$ secretion and the corresponding fluctuating gonadotropin values, which are influenced by pre-analytical, analytical (type of assay), and biological factors that may be different in diverse ethnic populations and sexes, studies including a large number of Korean children, both boys and girls, and data from various analytical platforms are needed $[15,16]$.

Therefore, in this study, we sought to evaluate GnRH stimulation test results through serial sampling at different time points to elucidate the prevalence of a pubertal response in Korean children who had undergone a GnRH stimulation test due to the suspicion of precocious puberty. We also aimed to determine which time points for blood sampling are ideal for the assessment of time to achieve the peak concentration of LH as well as concentrations over and below $5 \mathrm{IU} / \mathrm{L}$ after GnRH stimulation for the diagnosis of CPP in Korean children. 


\section{Materials and Methods}

\subsection{Study Populations}

From September 2017 to December 2018, GnRH stimulation test results from Korean females younger than eight years and 365 days, and from males younger than nine years and 365 days who visited one of 18 private pediatric clinics for LH measurement after GnRH stimulation were obtained from the laboratory information system of Green Cross Laboratories. Green Cross Laboratories is one of the largest referral clinical laboratories in Korea. When duplicate tests existed, only the patient's first results were included. Records missing age and sex data were excluded. All data were anonymized prior to analysis. Information about the GnRH stimulation test could not be evaluated because this retrospective study used anonymized laboratory test results. During the study period, 19,990 test results detailing the LH concentration after GnRH stimulation from 1958 Korean children (1841 females aged 1.3-8 years and 365 days, and 117 males aged 7.3-9 years and 365 days) were obtained. This study was conducted in accordance with the guidelines laid down in the Declaration of Helsinki, and all procedures involving human subjects were approved by the institutional review board of Green Cross Laboratories (GCL-2019-101004). The datasets generated and analyzed during the current study are available from the corresponding authors upon reasonable request.

\subsection{Definitions}

Pubertal response was defined as a peak LH hormone level of $5 \mathrm{IU} / \mathrm{L}$ or more, and more than 2 times the basal LH concentration after GnRH stimulation, according to previous literature and a national notification (2017-180) released by the Ministry of Health and Welfare of Korea regarding the use of GnRH agonists for the treatment of CPP [4,7,8,11-14]. Girls aged less than 8 years and 365 days, and boys aged less than 9 years and 365 days were included $[4,7,8,11-14]$. It has been reported that CPP patients show a pubertal response during GnRH stimulation testing [4,7,8,11-14]. The other participants were defined as showing a prepubertal response.

\subsection{Analytical Procedures}

Serum LH and FSH concentrations were measured using an ECLIA assay with Elecsys LH and Elecsys FSH (Roche Holding AG, Basel, Switzerland) in accordance with the manufacturer's instructions. The limit of quantification for both the LH and FSH assays was $0.3 \mathrm{IU} / \mathrm{L}$. The percentage coefficient of variation for the replicate analysis was $3.6 \%$ for the $\mathrm{LH}$ assay and $3.7 \%$ for the FSH assay in the range of 0.3 to $200 \mathrm{IU} / \mathrm{L}$.

\subsection{Statistical Analysis}

Categorical variables are presented as frequencies and percentages. The chi-square test was used to compare categorical variables. LH and FSH levels below the lower limit of quantification $(0.3 \mathrm{IU} / \mathrm{L}$ for $\mathrm{LH}$ and $0.3 \mathrm{IU} / \mathrm{L}$ for $\mathrm{FSH})$ were replaced by the value of the lower limit of quantification for the statistical analysis. We used nonparametric methods when data (continuous variables) were not normally distributed. To investigate the diagnostic value of $\mathrm{LH}$ at different time points after GnRH stimulation, we performed a receiver operating characteristic (ROC) curve analysis. Statistical analysis was executed using MedCalc software for Windows, version 19.1.3 (MedCalc Software bv, Ostend, Belgium). $p$ values were considered to be significant at a level of 0.05 .

\section{Results}

The characteristics of the study population of 1958 Korean children are summarized in Table 1. Among 1958 children, 1232 children (62.9\%) had pubertal responses (peak LH concentration $\geq 5 \mathrm{IU} / \mathrm{L}$ and more than 2 times the basal LH). Age, basal LH and FSH concentrations, peak LH and FSH concentrations, and the peak LH/FSH ratio were significantly different between the pubertal- and prepubertal-response groups $(p<0.05)$. 
The prevalence of children with a pubertal response was not significantly different between males and females $(p=0.064)$.

Table 1. Basal characteristics and gonadotropin-releasing hormone-stimulated hormone results.

\begin{tabular}{|c|c|c|c|c|c|c|c|c|c|c|}
\hline \multirow{3}{*}{ Variables $^{\text {a }}$} & \multicolumn{4}{|c|}{ Male $(n=117)$} & \multirow{3}{*}{$p^{*}$} & \multicolumn{4}{|c|}{ Female $(n=1841)$} & \multirow{3}{*}{$p^{*}$} \\
\hline & \multicolumn{2}{|c|}{$\begin{array}{c}\text { Prepubertal } \\
\text { Response }(n=34)\end{array}$} & \multicolumn{2}{|c|}{$\begin{array}{l}\text { Pubertal Response } \\
\quad(n=83)\end{array}$} & & \multicolumn{2}{|c|}{$\begin{array}{c}\text { Prepubertal } \\
\text { Response }(n=692)\end{array}$} & \multicolumn{2}{|c|}{$\begin{array}{l}\text { Pubertal Response } \\
\quad(n=1149)\end{array}$} & \\
\hline & Med & IQR & Med & IQR & & Med & IQR & Med & IQR & \\
\hline Age (years) & 9.1 & $8.6-9.6$ & 9.7 & $9.4-9.9$ & $<0.001$ & 8.2 & $6.2-8.8$ & 8.4 & $7.9-8.8$ & $<0.001$ \\
\hline Basal LH & 0.3 & $0.3-0.4$ & 0.9 & $0.4-1.7$ & $<0.001$ & 0.3 & $0.3-0.3$ & 0.3 & $0.3-0.4$ & $<0.001$ \\
\hline Basal FSH & 1.2 & $0.8-1.4$ & 2.3 & $1.7-3.2$ & $<0.001$ & 1.5 & $1.1-1.9$ & 2.3 & $1.8-3.2$ & $<0.001$ \\
\hline Peak LH & 3.3 & $2.4-3.9$ & 16.7 & $9.7-22.8$ & $<0.001$ & 3.4 & $2.6-4.2$ & 8.7 & $6.5-14.1$ & $<0.001$ \\
\hline Peak FSH & 5.3 & $3.5-6.5$ & 6.7 & $5.0-9.2$ & $<0.001$ & 11.5 & $9.0-14.3$ & 14.9 & $12.3-18.1$ & $<0.001$ \\
\hline $\begin{array}{l}\text { Peak LH/FSH } \\
\text { ratio }\end{array}$ & 0.6 & $0.5-0.8$ & 2.2 & $1.3-4.1$ & $<0.001$ & 0.3 & $0.2-0.4$ & 0.6 & $0.4-1.0$ & $<0.001$ \\
\hline
\end{tabular}

Abbreviations: FSH, follicle-stimulating hormone; LH, luteinizing hormone; Med, median; IQR, interquartile range ${ }^{a}$ Units for LH and FSH: IU/L. * $p$-values from the Mann-Whitney U test.

Different sampling times were incorporated during hormone analysis after GnRH stimulation, including the basal time point (0) and 15, 30, 45, 60, 90, and 120 min after GnRH stimulation. Hormone levels at each time point after GnRH stimulation are shown in Figure 1 and Table 2. The cumulative frequency of the pubertal response (time taken to achieve an LH concentration $\geq 5 \mathrm{IU} / \mathrm{L}$ and more than 2 times the basal LH), the time taken to achieve the peak LH concentration, and the time taken to decrease the LH level to below $5 \mathrm{IU} / \mathrm{mL}$ at each sampling time point during $\mathrm{GnRH}$ stimulation testing are summarized in Table 3. In 83 males with pubertal responses, it took 15 to $30 \mathrm{~min}$ to achieve more than 2 times the basal LH concentration and $\geq 5 \mathrm{IU} / \mathrm{L}$. It was observed that the time taken to reach the peak LH concentration was within $60 \mathrm{~min}$ in all males with a pubertal response but one (one boy had an LH concentration of $5 \mathrm{IU} / \mathrm{L}$ at $30 \mathrm{~min}$ and showed a peak LH concentration at $120 \mathrm{~min}$ after GnRH stimulation). In females, the time range was more varied than that seen in males. Among all children, $97.4 \%$ of males (114/117) and $96.6 \%$ of females (1779/1841) achieved their peak LH concentration within 60 min. Among the 1232 children who showed a pubertal response, $258(20.6 \%)$ showed a decrease in the LH concentration of below $5 \mathrm{IU} / \mathrm{L}$ after reaching the peak concentration. Of note, it took 45 to $120 \mathrm{~min}$ to achieved the decreased LH level of below $5 \mathrm{IU} / \mathrm{L}$ in all but one of these 258 children.

The ROC curves of LH at the different time points (basal (0) and 15, 30, 45, 60, 90, and 120 min after GnRH stimulation) are summarized in Figure 2 for all patients. The ROC curve for LH at $45 \mathrm{~min}$ after GnRH stimulation had the greatest area under the curve (AUC) in males, and that at $60 \mathrm{~min}$ after GnRH stimulation had the greatest AUC in females (Table 4). An additional ROC curve analysis for the combination of two time points showed that the combination of $45 \mathrm{~min}$ and $60 \mathrm{~min}$ produced the greatest AUC for both males and females (Table 4). 
(a)

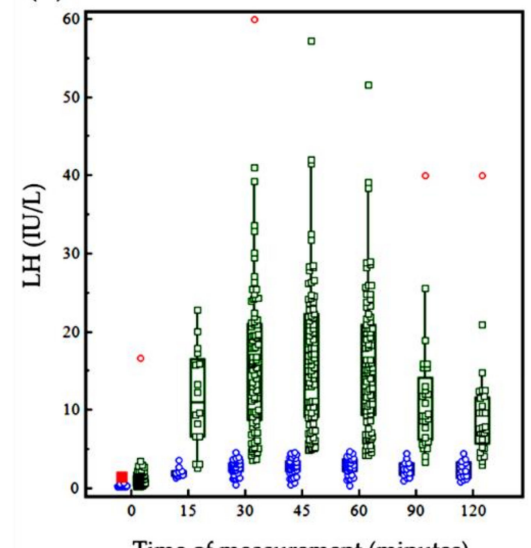

(c)

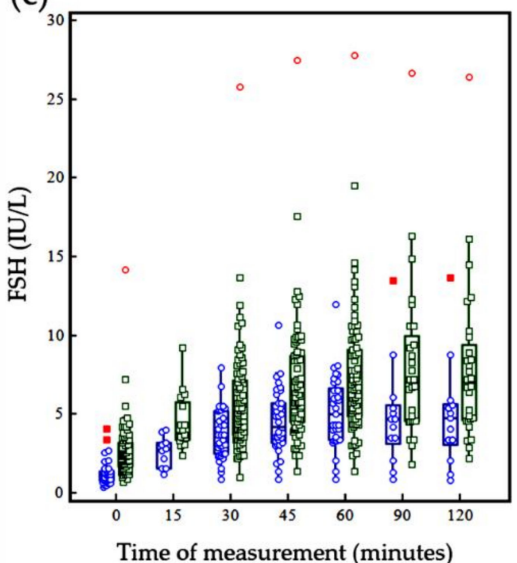

(b)

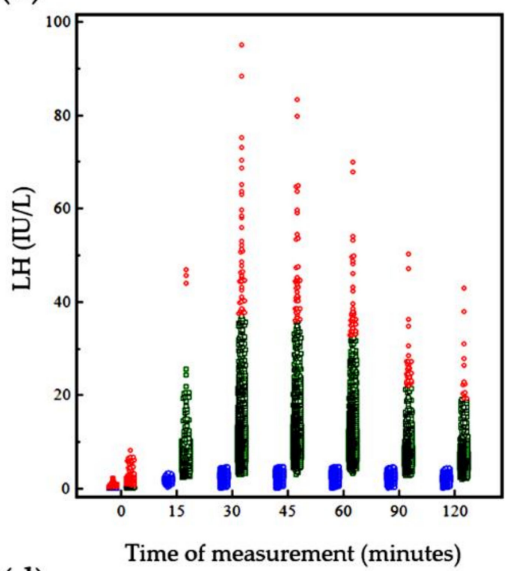

(d)

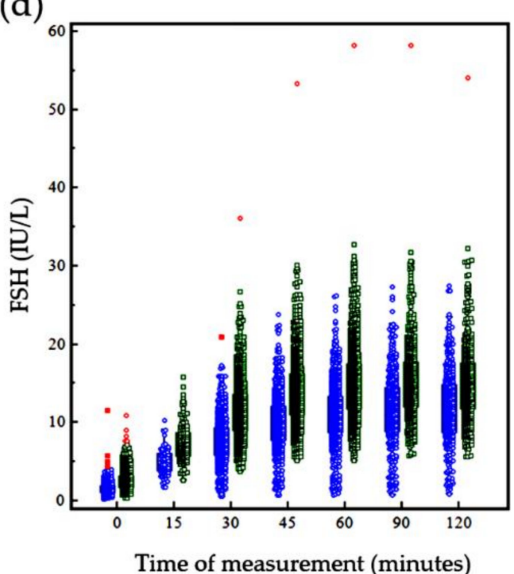

Figure 1. Gonadotropin-releasing hormone ( $\mathrm{GnRH})$-stimulated hormone results for the pubertalresponse group and the prepubertal-response group using the cutoff value of $5.0 \mathrm{IU} / \mathrm{L}$ or more and more than 2 times the basal LH concentration. (a) LH concentration in males; (b) LH concentration in females; (c) FSH concentration in males; (d) FSH concentration in females. In the figure, the central boxes represent the values from the 25-75 percentiles, and the middle line represents the median. Blue circles represent data from the prepubertal response group, and green squares represent data from the pubertal response group. Lines extend from the minimum to the maximum values, excluding outliers smaller than the lower quartile minus 1.5 times the interquartile range or larger than the upper quartile plus 1.5 times the interquartile range, known as inner fences, as well as values smaller than the lower quartile minus 3 times the interquartile range or larger than the upper quartile plus 3 times, known as outer fences. Outliers are plotted in red.

(a)

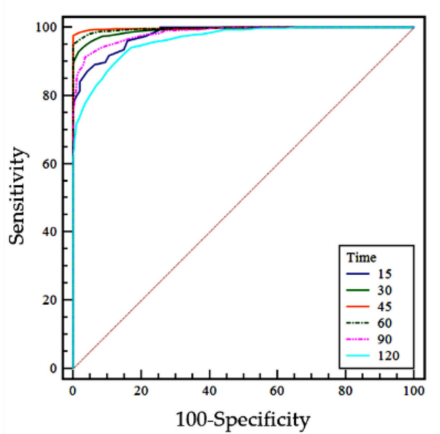

(b)

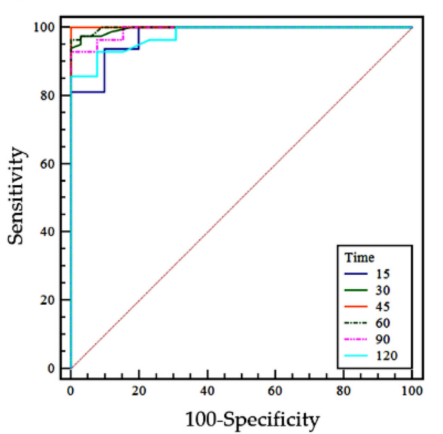

(c)

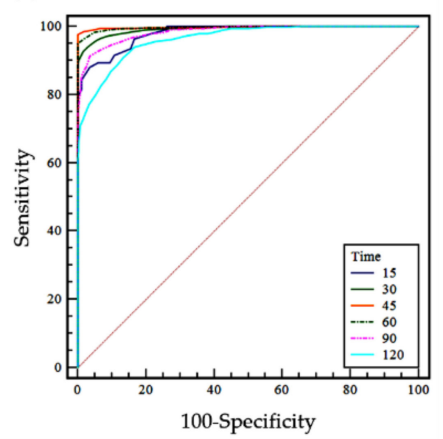

Figure 2. Receiver operating characteristic (ROC) curves of the LH at the basal time point (0) and 15, 30, 45, 60, 90, and 120 min after GnRH stimulation in (a) all patients, (b) males, and (c) females. The ROC curve analysis was performed to identify the best time point at which to differentiate pubertal responses using quantitative data for LH measurements. 
Table 2. Numbers and frequency (\%) of test results at each sampling time point during the GnRH stimulation test.

\begin{tabular}{|c|c|c|c|c|c|c|c|c|c|c|c|c|c|}
\hline & \multirow{2}{*}{$\begin{array}{c}\text { Basal } \\
n\end{array}$} & \multicolumn{2}{|c|}{$15 \mathrm{~min}$} & \multicolumn{2}{|c|}{$30 \mathrm{~min}$} & \multicolumn{2}{|c|}{$45 \mathrm{~min}$} & \multicolumn{2}{|c|}{$60 \mathrm{~min}$} & \multicolumn{2}{|c|}{$90 \mathrm{~min}$} & \multicolumn{2}{|c|}{$120 \mathrm{~min}$} \\
\hline & & $n$ & $\%$ & $n$ & $\%$ & $n$ & $\%$ & $n$ & $\%$ & $n$ & $\%$ & $n$ & $\%$ \\
\hline Male & 117 & 26 & 22.2 & 117 & 100.0 & 116 & 99.1 & 115 & 98.3 & 41 & 35.0 & 41 & 35.0 \\
\hline Pubertal response group & 83 & 16 & 19.3 & 83 & 100.0 & 82 & 98.8 & 82 & 98.8 & 28 & 33.7 & 28 & 33.7 \\
\hline First time to achieve $>2$ times the basal LH concentration and $\geq 5 \mathrm{IU} / \mathrm{L}$ & & 13 & 15.7 & 64 & 77.1 & 5 & 6.0 & 1 & 1.2 & 0 & 0.0 & 0 & 0.0 \\
\hline First time to reach peak the LH concentration & & 0 & 0.0 & 18 & 21.7 & 53 & 63.9 & 11 & 13.3 & 0 & 0.0 & 1 & 1.2 \\
\hline First time to decrease the $\mathrm{LH}$ concentration $<5 \mathrm{IU} / \mathrm{L}$ & & 0 & 0.0 & 0 & 0.0 & 1 & 14.3 & 3 & 42.9 & 0 & 0.0 & 3 & 42.9 \\
\hline Prepubertal response group & 34 & 10 & 29.4 & 34 & 100.0 & 34 & 100.0 & 33 & 97.1 & 13 & 38.2 & 13 & 38.2 \\
\hline First time to reach the peak LH concentration & 1 & 0 & 0.0 & 7 & 20.6 & 17 & 50.0 & 7 & 20.6 & 1 & 2.9 & 1 & 2.9 \\
\hline Female & 1841 & 226 & 12.3 & 1839 & 99.9 & 1769 & 96.1 & 1834 & 99.6 & 979 & 53.2 & 934 & 50.7 \\
\hline Pubertal response group & 1149 & 142 & 12.4 & 1147 & 99.8 & 1095 & 95.3 & 1148 & 99.9 & 582 & 50.7 & 555 & 48.3 \\
\hline First time to achieve $>2$ times the basal $\mathrm{LH}$ and $\geq 5 \mathrm{IU} / \mathrm{L}$ & & 90 & 7.8 & 926 & 80.6 & 113 & 9.8 & 17 & 1.5 & 1 & 0.1 & 2 & 0.2 \\
\hline First time to reach the peak LH concentration & & 1 & 0.1 & 414 & 36.0 & 598 & 52.0 & 118 & 10.3 & 7 & 0.6 & 11 & 1.0 \\
\hline First time to decrease the $\mathrm{LH}$ concentration $<5 \mathrm{IU} / \mathrm{L}$ & & 0 & 0.0 & 1 & 0.4 & 6 & 2.2 & 47 & 17.5 & 108 & 40.3 & 106 & 39.6 \\
\hline Prepubertal response group & 692 & 84 & 12.1 & 692 & 100.0 & 674 & 97.4 & 686 & 99.1 & 397 & 57.4 & 379 & 54.8 \\
\hline First time to reach the peak LH concentration & & 0 & 0.0 & 75 & 10.8 & 391 & 56.5 & 182 & 26.3 & 20 & 2.9 & 24 & 3.5 \\
\hline
\end{tabular}

Table 3. Number and cumulative frequency (\%) of test results at each sampling time point during the GnRH stimulation test.

\begin{tabular}{|c|c|c|c|c|c|c|c|c|c|c|c|c|c|}
\hline & \multirow{2}{*}{$\begin{array}{c}\text { Basal } \\
n\end{array}$} & \multicolumn{2}{|c|}{$15 \mathrm{~min}$} & \multicolumn{2}{|c|}{$30 \mathrm{~min}$} & \multicolumn{2}{|c|}{45 min } & \multicolumn{2}{|c|}{$60 \mathrm{~min}$} & \multicolumn{2}{|c|}{$90 \mathrm{~min}$} & \multicolumn{2}{|c|}{120 min } \\
\hline & & $n$ & $\%$ & $n$ & $\%$ & $n$ & $\%$ & $n$ & $\%$ & $n$ & $\%$ & $n$ & $\%$ \\
\hline Male & 117 & & & & & & & & & & & & \\
\hline Pubertal response group & 83 & & & & & & & & & & & & \\
\hline LH concentration reached $>2$ times the basal LH and $\geq 5 \mathrm{IU} / \mathrm{L}$ & & 16 & 19.3 & 77 & 92.8 & 82 & 98.8 & 83 & 100 & 0 & 100 & 0 & 100 \\
\hline Peak LH concentration reached & & 0 & 0 & 18 & 21.7 & 71 & 85.5 & 82 & 98.8 & 82 & 98.8 & 83 & 100 \\
\hline LH concentration decreased to $<5 \mathrm{IU} / \mathrm{L}$ & & 0 & 0 & 0 & 0 & 1 & 14.3 & 4 & 57.1 & 4 & 57.1 & 7 & 100 \\
\hline Prepubertal response group & 34 & & & & & & & & & & & & \\
\hline Peak LH concentration reached & 1 & 0 & 0 & 8 & 23.5 & 25 & 73.5 & 32 & 94.1 & 33 & 97.1 & 34 & 100 \\
\hline Pubertal response group & 1149 & & & & & & & & & & & & \\
\hline LH concentration reached $>2$ times the basal $\mathrm{LH}$ and $\geq 5 \mathrm{IU} / \mathrm{L}$ & & 90 & 7.8 & 1016 & 88.4 & 1129 & 98.3 & 1146 & 99.7 & 1147 & 99.8 & 1149 & 100 \\
\hline Peak LH concentration reached & & 1 & 0.1 & 415 & 36.1 & 1013 & 88.2 & 1131 & 98.4 & 1138 & 99.0 & 1149 & 100 \\
\hline $\mathrm{LH}$ concentration decreased to $<5 \mathrm{IU} / \mathrm{L}$ & & 0 & 0 & 1 & 0.4 & 7 & 2.6 & 54 & 20.1 & 162 & 60.4 & 268 & 100 \\
\hline Prepubertal response group & 692 & & & & & & & & & & & & \\
\hline Peak LH concentration reached & & 0 & 0 & 75 & 10.8 & 466 & 67.3 & 648 & 93.6 & 668 & 96.5 & 692 & 100 \\
\hline
\end{tabular}




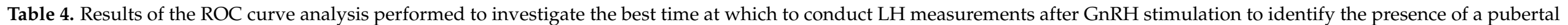
response.

\begin{tabular}{|c|c|c|c|c|c|c|c|c|c|c|c|c|}
\hline \multirow[b]{2}{*}{ Rank } & \multicolumn{4}{|c|}{ Total $(n=1958)$} & \multicolumn{4}{|c|}{ Male $(n=117)$} & \multicolumn{4}{|c|}{ Female $(n=1841)$} \\
\hline & $\begin{array}{l}\text { Time of } \\
\text { Measure }\end{array}$ & AUC & SE & $95 \% \mathrm{CI}$ & $\begin{array}{c}\text { Time of } \\
\text { Measure }\end{array}$ & AUC & SE & $95 \%$ CI & $\begin{array}{c}\text { Time of } \\
\text { Measure }\end{array}$ & AUC & SE & $95 \% \mathrm{CI}$ \\
\hline 1 & $45 \& 60 \mathrm{~min}$ & 0.996 & 0.001 & 0.991 to 0.998 & $45 \& 60 \mathrm{~min}$ & 0.994 & 0.006 & 0.958 to 1.000 & $45 \& 60 \mathrm{~min}$ & 0.996 & 0.001 & 0.991 to 0.998 \\
\hline 2 & $30 \& 45 \mathrm{~min}$ & 0.991 & 0.002 & 0.986 to 0.995 & $30 \& 45 \mathrm{~min}$ & 0.994 & 0.006 & 0.958 to 1.000 & $30 \& 45 \mathrm{~min}$ & 0.991 & 0.002 & 0.986 to 0.995 \\
\hline 3 & $30 \& 60 \mathrm{~min}$ & 0.987 & 0.002 & 0.980 to 0.991 & $30 \& 60 \mathrm{~min}$ & 0.988 & 0.008 & 0.948 to 0.999 & $30 \& 60 \mathrm{~min}$ & 0.987 & 0.002 & 0.980 to 0.991 \\
\hline 4 & $45 \& 90 \mathrm{~min}$ & 0.986 & 0.002 & 0.980 to 0.991 & 45 \& $90 \mathrm{~min}$ & 0.988 & 0.008 & 0.948 to 0.999 & $45 \& 90 \mathrm{~min}$ & 0.986 & 0.002 & 0.980 to 0.991 \\
\hline 5 & $45 \& 120 \mathrm{~min}$ & 0.985 & 0.002 & 0.979 to 0.990 & $45 \& 120 \mathrm{~min}$ & 0.988 & 0.008 & 0.948 to 0.999 & $45 \& 120 \mathrm{~min}$ & 0.985 & 0.003 & 0.978 to 0.990 \\
\hline 6 & $60 \& 120 \mathrm{~min}$ & 0.976 & 0.003 & 0.968 to 0.982 & $45 \mathrm{~min}$ & 0.982 & 0.010 & 0.938 to 0.998 & $60 \& 90 \mathrm{~min}$ & 0.976 & 0.003 & 0.968 to 0.982 \\
\hline 8 & $60 \& 90 \mathrm{~min}$ & 0.975 & 0.003 & 0.967 to 0.982 & $30 \& 90 \mathrm{~min}$ & 0.982 & 0.010 & 0.938 to 0.998 & $60 \mathrm{~min}$ & 0.975 & 0.003 & 0.967 to 0.981 \\
\hline 9 & $60 \mathrm{~min}$ & 0.974 & 0.003 & 0.966 to 0.981 & $15 \& 60 \mathrm{~min}$ & 0.976 & 0.012 & 0.929 to 0.995 & $15 \& 60 \mathrm{~min}$ & 0.975 & 0.003 & 0.967 to 0.981 \\
\hline 10 & $15 \& 45 \mathrm{~min}$ & 0.968 & 0.004 & 0.959 to 0.975 & $60 \mathrm{~min}$ & 0.970 & 0.013 & 0.920 to 0.993 & $45 \mathrm{~min}$ & 0.966 & 0.004 & 0.957 to 0.974 \\
\hline 11 & $45 \mathrm{~min}$ & 0.967 & 0.004 & 0.958 to 0.975 & $30 \& 120 \mathrm{~min}$ & 0.970 & 0.013 & 0.920 to 0.993 & $15 \& 45 \mathrm{~min}$ & 0.966 & 0.004 & 0.957 to 0.974 \\
\hline 12 & $30 \& 90 \mathrm{~min}$ & 0.956 & 0.004 & 0.946 to 0.964 & $60 \& 90 \mathrm{~min}$ & 0.970 & 0.013 & 0.920 to 0.993 & $30 \& 90 \mathrm{~min}$ & 0.954 & 0.004 & 0.943 to 0.963 \\
\hline 13 & $30 \& 120 \mathrm{~min}$ & 0.951 & 0.004 & 0.941 to 0.960 & $60 \& 120 \mathrm{~min}$ & 0.970 & 0.013 & 0.920 to 0.993 & $30 \& 120 \mathrm{~min}$ & 0.950 & 0.004 & 0.939 to 0.959 \\
\hline 14 & $15 \& 30 \mathrm{~min}$ & 0.944 & 0.005 & 0.932 to 0.953 & $30 \mathrm{~min}$ & 0.964 & 0.014 & 0.912 to 0.990 & $30 \mathrm{~min}$ & 0.942 & 0.005 & 0.930 to 0.952 \\
\hline 15 & $30 \mathrm{~min}$ & 0.943 & 0.005 & 0.932 to 0.953 & $15 \& 30 \mathrm{~min}$ & 0.964 & 0.014 & 0.912 to 0.990 & $15 \& 30 \mathrm{~min}$ & 0.942 & 0.005 & 0.930 to 0.952 \\
\hline 16 & $15 \& 90 \mathrm{~min}$ & 0.730 & 0.007 & 0.710 to 0.750 & $15 \& 90 \mathrm{~min}$ & 0.735 & 0.028 & 0.645 to 0.812 & $15 \& 90 \mathrm{~min}$ & 0.730 & 0.007 & 0.709 to 0.750 \\
\hline 18 & $90 \mathrm{~min}$ & 0.689 & 0.007 & 0.668 to 0.710 & $15 \mathrm{~min}$ & 0.705 & 0.027 & 0.613 to 0.786 & $90 \mathrm{~min}$ & 0.691 & 0.007 & 0.670 to 0.713 \\
\hline 19 & $15 \& 120 \mathrm{~min}$ & 0.679 & 0.007 & 0.657 to 0.699 & $90 \mathrm{~min}$ & 0.657 & 0.026 & 0.563 to 0.742 & $15 \& 120 \mathrm{~min}$ & 0.676 & 0.007 & 0.654 to 0.697 \\
\hline 20 & $15 \mathrm{~min}$ & 0.655 & 0.007 & 0.633 to 0.676 & $90 \& 120 \mathrm{~min}$ & 0.657 & 0.026 & 0.563 to 0.742 & $15 \mathrm{~min}$ & 0.651 & 0.007 & 0.629 to 0.673 \\
\hline 21 & $120 \mathrm{~min}$ & 0.637 & 0.006 & 0.615 to 0.659 & $120 \mathrm{~min}$ & 0.639 & 0.025 & 0.545 to 0.725 & $120 \mathrm{~min}$ & 0.637 & 0.007 & 0.615 to 0.659 \\
\hline
\end{tabular}

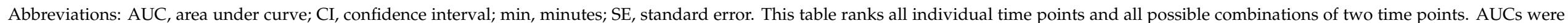
calculated to identify the best time point at which to differentiate pubertal responses using binary results based on a defined LH concentration (LH $\geq 5$ IU/L and more than 2 times the basal LH). 


\section{Discussion}

In this study, we evaluated the LH test results after GnRH stimulation according to different time points after stimulation using automated ECLIA methods in Korean children. Because it has been reported that LH levels vary according to the assay used, and because there are limited data on the LH concentration after GnRH stimulation available in children collected using ECLIA methods, these updated data from a relatively large sample size provide useful information about when to conduct GnRH stimulation testing in Korean children with this assay [2]. Furthermore, previous studies performed in Korea used data from only girls (Table 5). In Korea, the incidence and prevalence (per 100,000 persons) of CPP in boys is less than that in girls (incidence is 262.8 in girls and 7.0 in boys; prevalence is 410.6 in girls and 10.9 in boys) [20]. The lower prevalence and incidence in boys than in girls have also been reported in other ethnic populations, such as in Danish and Spanish children [20]. However, there are limited data from boys regarding the ideal blood-sampling time for the diagnosis of CPP via the GnRH stimulation test $[6,16]$. The strength of this study is the inclusion of a relatively large dataset from Korean boys.

Previous studies performed in Korean girls using analytical methods other than ECLIA reported that 30 or 45 min was the best time point for blood sampling after $\mathrm{GnRH}$ stimulation [7,11-14]. In this study, the ROC curve analysis for this single time point showed that the greatest AUC value for the LH concentration in males occurred at $45 \mathrm{~min}$, and this result had high levels of sensitivity and specificity. In females, LH measurement at $60 \mathrm{~min}$ achieved the greatest AUC value. More than $45 \mathrm{~min}$ was needed to achieve an $\mathrm{LH}$ concentration of $5 \mathrm{IU} / \mathrm{L}$ or more, and more than 2 times the basal LH concentration in four of the 1232 children who showed a pubertal response. In three of these four children, $120 \mathrm{~min}$ passed before the achievement of this LH concentration. Meanwhile, it took only $30 \mathrm{~min}$ to achieve an LH concentration of $5 \mathrm{IU} / \mathrm{L}$ or more, and more than 2 times the basal LH after GnRH stimulation in all males who showed a pubertal response. However, in females, the response rate was slow and more variable than that in males. In this study, data from more girls with a greater age range than boys were included, and the dispersion of the corresponding optimal times was greater in females than in males. It has been reported that fertility hormone change is complex and depends on age and sex during growth and puberty [15]. LH and FSH markedly increase during puberty in females, but this occurs to a lesser extent in males $[15,16]$. The results of this study are comparable with previous findings regarding the complexity and extent of hormone changes by age and sex, although clinical information is limited. Future studies including large numbers of subjects with different ages and corresponding clinical information are needed to clarify the different hormone changes that occur and to determine the optimal time points at which to measure LH after GnRH stimulation.

Results from a considerable (20.6\%) portion of children with pubertal responses showed decreased LH concentrations below $5 \mathrm{IU} / \mathrm{L}$ at 45 to $120 \mathrm{~min}$ after $\mathrm{GnRH}$ stimulation, while LH concentrations were decreased below $5 \mathrm{IU} / \mathrm{L}$ at $45 \mathrm{~min}$ after $\mathrm{GnRH}$ stimulation in seven children in this study. Among 1177 patients with pubertal responses whose blood was drawn at $45 \mathrm{~min}, 26(2.2 \%)$ would not have been identified as having a pubertal response in this study if a single 45-min sampling method was applied. 
Table 5. Studies performed to investigate the best time to measure LH after GnRH stimulation to diagnose central precocious puberty in children.

\begin{tabular}{|c|c|c|c|c|c|c|}
\hline Reference & Study Region & Subjects & Analytical Methods & $\begin{array}{l}\text { Investigated } \\
\text { Measurement Times }\end{array}$ & $\begin{array}{l}\text { Best Time to Measure } \\
\text { LH }\end{array}$ & $\begin{array}{l}\text { Criteria for Selection of the } \\
\text { Best Time Point in the Study }\end{array}$ \\
\hline $\begin{array}{l}\text { Kandemir et al., } 2011 \\
\text { [17] }\end{array}$ & Turkey & 263 girls & CLIA, Architect system & $\begin{array}{l}\text { Basal and after 20, 40, 60, } \\
\text { and } 90 \text { min }\end{array}$ & $40 \mathrm{~min}$ & $\begin{array}{l}\text { Highest AUC (sensitivity } 98 \% \text {, } \\
\text { specificity } 100 \% \text { ) }\end{array}$ \\
\hline Yazdani et al., 2012 [18] & USA & $\begin{array}{l}107 \text { children } \\
16 \text { boys, } 91 \text { girls }\end{array}$ & CLIA, ADVIA Centaur System & $\begin{array}{l}\text { Basal and after } 1,3 \text {, and } \\
6 \mathrm{~h}\end{array}$ & $3 \mathrm{~h}$ & $\begin{array}{l}\text { Highest cumulative frequency } \\
\text { in CPP patients }(100 \%)\end{array}$ \\
\hline Cavallo et al., 1995 [19] ${ }^{a}$ & USA & $\begin{array}{l}44 \text { girls } \\
7 \text { boys }\end{array}$ & IMRA & $\begin{array}{l}\text { Basal and after } 15,30,45, \\
\text { and } 60 \text { min (Cincinnati) } \\
\text { Basal and after 10, 20, 30, } \\
45 \text {, and } 60 \text { min (Chicago) }\end{array}$ & Between $30-60 \min ^{a}$ & $\begin{array}{l}\text { Visual inspection of ROC } \\
\text { curves }^{\text {a }}\end{array}$ \\
\hline Choi et al., 2007 [11] & Korea & 45 girls & IMRA & $\begin{array}{l}\text { Basal and after } 15,30, \\
60,90 \text {, and } 120 \mathrm{~min}\end{array}$ & $30 \mathrm{~min}$ & $\begin{array}{l}\text { Highest sensitivity to the } \\
\text { diagnosis of CPP (sensitivity } \\
100 \% \text {, specificity } 78.9 \% \text { ) }\end{array}$ \\
\hline Kim et al., 2016 [12] & Korea & 118 girls & IMRA & $\begin{array}{l}\text { Basal and after } 30,45, \\
\text { and } 60 \mathrm{~min}\end{array}$ & $30 \mathrm{~min}$ & $\begin{array}{l}\text { Highest frequency in CPP } \\
\text { patients }(82.5 \%)\end{array}$ \\
\hline Yun et al., 2017 [13] & Korea & 69 girls & IMRA & $\begin{array}{l}\text { Basal and after } 30,60,90, \\
\text { and } 120 \text { min }\end{array}$ & $30 \mathrm{~min}$ & $\begin{array}{l}\text { Highest cumulative frequency } \\
\text { in CPP patients }(100 \%)\end{array}$ \\
\hline Kim et al., 2015 [14] & Korea & 72 girls & CLIA, Architect system & $\begin{array}{l}\text { Basal and after } 15,30,45, \\
60,90 \text {, and } 120 \mathrm{~min}\end{array}$ & $45 \mathrm{~min}$ & $\begin{array}{l}\text { Highest cross-sectional }(98.6 \%) \\
\text { and cumulative frequencies } \\
(100 \%)\end{array}$ \\
\hline Kim et al. 2011 [7] & Korea & 166 girls & CLIA, ADVIA Centaur System & $\begin{array}{l}\text { Basal and after } 15,30,45, \\
60,90 \text {, and } 120 \mathrm{~min}\end{array}$ & $45 \mathrm{~min}$ & $\begin{array}{l}\text { Highest cumulative frequency } \\
\text { in CPP patients }(100 \%)\end{array}$ \\
\hline This study & Korea & $\begin{array}{l}1958 \text { children } \\
117 \text { boys } \\
1841 \text { girls }\end{array}$ & ECLIA, Cobas system & $\begin{array}{l}\text { Basal and after } 15,30,45, \\
60,90 \text {, and } 120 \mathrm{~min}\end{array}$ & $\begin{array}{l}60 \min (99.8 \%)^{b} \\
45 \min (100 \%)^{b} \\
60 \min (99.7 \%)^{b}\end{array}$ & $\begin{array}{l}\text { Highest AUC (sensitivity } \\
95.0 \% \text {, specificity } 100 \% \text { ) } \\
\text { Highest AUC (sensitivity } \\
97.6 \% \text {, specificity } 100 \% \text { ) } \\
\text { Highest AUC (sensitivity } \\
97.8 \% \text {, specificity } 100 \% \text { ) }\end{array}$ \\
\hline
\end{tabular}

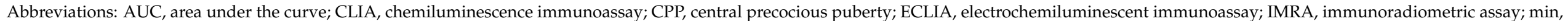

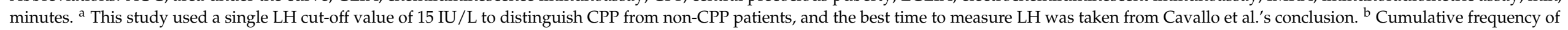
pubertal responses based on the time of measuring the LH level among patients with a pubertal response (presented in parentheses). 
Although some previous studies discussed the use of two time points for blood sampling based on their results, they did not perform a statistical analysis using the ROC curve analysis with the combination of two time points [7,11-16]. An additional ROC curve analysis for the combination of two time points showed that the combination of $45 \mathrm{~min}$ and $60 \mathrm{~min}$ produced the greatest AUC in this study. These findings suggest that multiple sampling time points are needed to diagnose CPP. The difference in the best LH measurement time identified among studies might be due to differences in the analytical methods used to quantify $\mathrm{LH}$, the injection conditions of GnRH for stimulation, and the cohort characteristics, such as sex and age [1,2]. In South Korea, a standard dose of GnRH $(100 \mu \mathrm{g})$ is given to diagnose CPP, while other countries may use a GnRH dose that is weight-adapted or adapted to the body surface of patients [6]. Future studies are needed to identify the best timing for LH measurement after GnRH stimulation to diagnose CPP with consideration of these factors to reach a consensus [6,21].

The European Society for Paediatric Endocrinology and the Endocrine Society define Precocious puberty as puberty that starts before age 8 in girls and 9 in boys, definitions that are different from those used in the present study ( 8 years and 365 days for girls and 9 years and 365 days for boys, based on criteria for reimbursable CPP treatment in Korea) $[8,10]$. This difference may limit the generalizability of the results of this study to other ethnic populations.

The limitation of this study is the lack of details pertaining to the patients' personal history and the conduct of physical examinations to assess puberty such as Tanner staging and other laboratory and imaging tests to diagnose CPP. The lack of information weakens the study and makes it less generalizable to children with clinical signs of CPP. However, because the gold standard for the laboratory diagnosis of CPP is based on LH measurements after GnRH stimulation [1], this study still has value. The results of this study may be generalizable to populations in which a standard dose of GnRH $(100 \mu \mathrm{g})$ is used and LH is measured using the ECLIA method to diagnose CPP. Furthermore, the use of recently collected data from a relatively large number of Korean children who underwent GnRHstimulated hormone testing gives strength to this study. However, future studies are needed to investigate appropriate $\mathrm{GnRH}$ stimulation test strategies to diagnosis CPP using a variety of clinical information and to elucidate the best time points for sampling in various ethnic populations using different measurement methods.

\section{Conclusions}

In conclusion, we investigated hormone results after $\mathrm{GnRH}$ stimulation testing to identify the presence of CPP in Korean children. Considering the time points necessary to achieve the peak LH concentration and to decrease the LH level below the cut-off value of $5.0 \mathrm{IU} / \mathrm{L}$, multiple time points, including $45 \mathrm{~min}$ and $60 \mathrm{~min}$, need to be assessed in relation to GnRH stimulation test outcomes for the ECLIA assay used in this study. The results of this study provide useful information about the clinical application of GnRH stimulation testing.

Author Contributions: Conceptualization, R.C. and S.G.L.; methodology, R.C., A.K. and Y.O.; software, R.C.; validation, R.C. and S.G.L.; formal analysis, R.C.; investigation, R.C.; resources, R.C., A.K., Y.O., S.G.L. and E.H.L.; data curation, R.C.; writing-original draft preparation, R.C.; writingreview and editing, R.C., S.G.L. and E.H.L.; visualization, R.C.; supervision, S.G.L. and E.H.L.; project administration, R.C.; funding acquisition, S.G.L. and E.H.L. All authors have read and agreed to the published version of the manuscript.

Funding: This work was supported by Roche Diagnostics Korea (000264). The APC was funded by Roche Diagnostics Korea. The sponsor was not involved in the study design, data interpretation, or writing of the manuscript. The authors have no other relevant financial interest in the products or companies described in this article to report. 
Institutional Review Board Statement: This study was conducted according to the guidelines of the Declaration of Helsinki, and approved by the institutional review board of Green Cross Laboratories (GCL-2019-1010-04, 24 April 2020).

Informed Consent Statement: A waiver of informed consent was approved by the IRB (GCL-20191010-04, 24 April 2020) since the waiver would not adversely affect the rights and welfare of the subjects because the study was retrospective and involved no more than minimal risk to the subjects.

Data Availability Statement: The datasets generated and analyzed during the current study are available from the corresponding authors upon reasonable request.

Acknowledgments: We would like to thank Hyunjoo Son and Jiseon Kim at Green Cross Laboratories for their administrative support. We would like to thank Park at the Graduate School of Pusan National University and Nambeom Kim at the Department of Biomedical Engineering Research Center, Gachon University for their advice on the statistical analyses.

Conflicts of Interest: The authors declare no conflict of interest.

\section{References}

1. Latronico, A.C.; Brito, V.N.; Carel, J.C. Causes, diagnosis, and treatment of central precocious puberty. Lancet Diabetes Endocrinol. 2016, 4, 265-274. [CrossRef]

2. Carel, J.C.; Leger, J. Clinical practice. Precocious puberty. N. Engl. J. Med. 2008, 358, 2366-2377. [CrossRef] [PubMed]

3. Wei, C.; Davis, N.; Honour, J.; Crowne, E. The investigation of children and adolescents with abnormalities of pubertal timing. Ann. Clin. Biochem. 2017, 54, 20-32. [CrossRef] [PubMed]

4. Rhie, Y.J.; Lee, K.H. Overview and treatment of precocious puberty. J. Korean Med. Assoc. 2015, 58, 1138-1144. [CrossRef]

5. Kim, S.H.; Huh, K.; Won, S.; Lee, K.W.; Park, M.J. A Significant Increase in the Incidence of Central Precocious Puberty among Korean Girls from 2004 to 2010. PLoS ONE 2015, 10, e0141844. [CrossRef] [PubMed]

6. Krishna, K.B.; Fuqua, J.S.; Rogol, A.D.; Klein, K.O.; Popovic, J.; Houk, C.P.; Charmandari, E.; Lee, P.A.; Freire, A.V.; Ropelato, M.G.; et al. Use of Gonadotropin-Releasing Hormone Analogs in Children: Update by an International Consortium. Horm. Res. Paediatr. 2019, 91, 357-372.

7. Kim, H.K.; Kee, S.J.; Seo, J.Y.; Yang, E.M.; Chae, H.J.; Kim, C.J. Gonadotropin-releasing hormone stimulation test for precocious puberty. Korean J. Lab. Med. 2011, 31, 244-249. [CrossRef] [PubMed]

8. The Korean Society of Pediatric Endocrinology. The Korean Society of Pediatric Endocrinology's Clinical Guideline for the Management of Precocious Puberty; The Korean Society of Pediatric Endocrinology: Seoul, Korea, 2011.

9. Neely, E.K.; Hintz, R.L.; Wilson, D.M.; Lee, P.A.; Gautier, T.; Argente, J.; Stene, M. Normal ranges for immunochemiluminometric gonadotropin assays. J. Pediatr. 1995, 127, 40-46. [CrossRef]

10. Carel, J.C.; Eugster, E.A.; Rogol, A.; Ghizzoni, L.; Palmert, M.R.; Antoniazzi, F.; Berenbaum, S.; Bourguignon, J.; Chrousos, G.P.; ESPE-LWPES GnRH Analogs Consensus Conference Group; et al. Consensus statement on the use of gonadotropin-releasing hormone analogs in children. Pediatrics 2009, 123, e752-e762. [CrossRef] [PubMed]

11. Choi, J.-H.; Shin, Y.-L.; Yoo, H.-W. Predictive factors for organic central precocious puberty and utility of simplified gonadotropinreleasing hormone tests. Pediatr. Int. 2007, 49, 806-810. [CrossRef] [PubMed]

12. Kim, J.-I.; Kwon, W.-H.; Moon, K.-C.; Lee, I.-W. Clinical Characteristics of precocious puberty girls and Comparison Analysis of GnRH Test results with Diagnosis type. J. Nucl. Med. Technol. 2016, 20, 54-60.

13. Yun, B.S.; Kim, K.H. Gonadotropin-Releasing Hormone Stimulation Test in Patients with Precocious Puberty. Korean J. Natl. Health Insur. Serv. Ilsan Hosp. 2017, 16, 125-129.

14. Kim, M.S.; Hwang, P.H.; Lee, D.-Y. A Gonadotropin-Releasing Hormone (GnRH) Stimulation Test Before and After GnRH Analogue Treatment for Central Precocious Puberty: Has the GnRH Test been Adequately Simplified? Indian J. Pediatr. 2015, 82, 996-1000. [CrossRef] [PubMed]

15. Adeli, K.; Higgins, V.; Trajcevsk, K.; Habeeb, N.-W. The Canadian laboratory initiative on pediatric reference intervals: A CALIPER white paper. Crit. Rev. Clin. Lab. Sci. 2017, 54, 358-413. [CrossRef] [PubMed]

16. Higgins, V.; Fung, A.W.S.; Chan, M.K.; Macri, J.; Adeli, K. Pediatric reference intervals for 29 Ortho VITROS 5600 immunoassays using the CALIPER cohort of healthy children and adolescents. Clin. Chem. Lab. Med. 2018, 26, 327-340. [CrossRef]

17. Kandemir, N.; Demirbilek, H.; Ozon, Z.A.; Gonc, N.; Alikasifoglu, A. GnRH stimulation test in precocious puberty: Single sample is adequate for diagnosis and dose adjustment. J. Clin. Res. Pediatr. Endocrinol. 2011, 3, 12-17. [CrossRef]

18. Yazdani, P.; Lin, Y.; Raman, V.; Haymond, M. A single sample GnRHa stimulation test in the diagnosis of precocious puberty. Int. J. Pediatr. Endocrinol. 2012, 23, 1-6. [CrossRef] [PubMed]

19. Cavallo, A.; Richards, G.E.; Busey, S.; Michaels, S.E. A simplified gonadotrophin-releasing hormone test for precocious puberty. Clin. Endocrinol. (Oxf.) 1995, 42, 641-646. [CrossRef] [PubMed] 
20. Kim, Y.J.; Kwon, A.; Jung, M.K.; Kim, K.E.; Suh, J.; Chae, H.W.; Kim, D.H.; Ha, S.; Seo, G.H.; Kim, H. Incidence and Prevalence of Central Precocious Puberty in Korea: An Epidemiologic Study Based on a National Database. J. Pediatr. 2019, 208, 221-228. [CrossRef] [PubMed]

21. Brito, V.N.; Spinola-Castro, A.M.; Kochi, C.; Kopacek, C.; da Silva, P.C.A.; Guerra-Junior, G. Central precocious puberty: Revisiting the diagnosis and therapeutic management. Arch. Endocrinol. Metab. 2016, 60, 163-172. [CrossRef] [PubMed] 